\title{
Effects of Pharmaceutical Effluents on the Chemical Composition of Various Vegetables in Sahiwal Region Punjab, Pakistan
}

\author{
Muhammad Nasir Javed ${ }^{1}$, Sami Ullah", , Abid Ali ${ }^{2, ~ *, ~ M u h a m m a d ~ Z e s h a n ~}{ }^{2, ~ *, ~ K a n w a l ~ S h e h z a d i ~}{ }^{3}$, \\ Muhammad Khalid ${ }^{4}$ \\ ${ }^{1}$ Department of Biochemistry, Government College University, Faisalabad, Pakistan \\ ${ }^{2}$ Department of Chemistry, University of Lahore Sargodha Campus, Punjab, Pakistan \\ ${ }^{3}$ Department of Chemistary Govt.Post Graduate College Samnabad, Faisalabad, Punjab, Pakistan \\ ${ }^{4}$ Department of Chemistry, Government College University, Faisalabad, Pakistan \\ Email address: \\ m.nasirjaved193@gmail.com (M. N. Javed), Dr.Sami.online@gmail.com (S. Ullah), abidali6972@gmail.com (A. Ali), \\ muhammadzeeshanchem@gmail.com (M. Zeshan), shehzadikanwal742@gmail.com (K. Shehzadi), ranakhalid993@gmail.com (M. Khalid) \\ ${ }^{*}$ Corresponding author
}

\section{To cite this article:}

Muhammad Nasir Javed, Sami Ullah, Abid Ali, Muhammad Zeshan, Kanwal Shehzadi, Muhammad Khalid. Effects of Pharmaceutical Effluents on the Chemical. Composition of Various Vegetables in Sahiwal Region Punjab, Pakistan. Chemical and Biomolecular Engineering. Vol. 5, No. 2, 2020, pp. 45-50. doi: 10.11648/j.cbe.20200502.11

Received: January 2, 2020; Accepted: February 27, 2020; Published: May 28, 2020

\begin{abstract}
The aim of this study was to determine the concentration of toxic metals such as Lead (pb), Chromium (Cr), Zinc $(\mathrm{Zn})$, Copper $(\mathrm{Cu})$, Iron $(\mathrm{Fe})$ and Cadmium $(\mathrm{Cd})$ in pharmaceutical effluents, agricultural soil and vegetables (Pumpkin, Green Chilli and Spinach) in Sahiwal Region, Punjab, Pakistan, where many pharmaceutical industries producing effluents that contain toxic metals, reagents, organic compounds and catalyst. These pharmaceutical effluents are being used for irrigation purpose. Different samples of efflents, soil and vegitables analysed. Though the detected amounts are exceeded from WHO irrigation limits in water samples other than zinc. The analysis of soil sample showed that All metals were exceeding the controlled sample and WHO limits. The testing in vegetables samples showed that all the metals exceeded the permissible limit other than Fe and it was concluded that agricultural soil and vegetables of small industrial estate area of Sahiwal region were contaminated by increasing concentration of toxic metals due to untreated pharmaceutical effluents. There is a need of regular monitoring of pharmaceutiocal effluents enterimg into irrigation water sources in order to save quality of vegatables and health hazards.
\end{abstract}

Keywords: Pharmaceutical Effluents, Soil, Vegetables, Toxic Metals

\section{Introduction}

Sahiwal is a famous city of south Punjab situated about 20 km away from River Ravi Punjab Pakistan. Different pharmaceutical industries like (M/S pharmaceutical industries, Kohinoor pharmaceutical industries, working in this city in small industrial area Sahiwal, producing many Pharmaceutical compounds. But these industries have released very toxic substances in the natural sources [1]. The effluents from these pharmaceutical industries discharged into small canal which goes from west side of industrial estate Sahiwal. These effluents are a fresh water resources for irrigation in this area

Effluents are harmful wastage of industries excrete through water in waste water bodies Many Studies have reported in their documents that disposal of these effluents directly to land and fresh water bodies has potential to contaminate them as well as air, soils and crops grown on these soils which will have diverse effect on human health. They are found in the naturally occurring ecosystems with large 
variety of concentrations [2]. and they have been associated the potential for irrigating about 21 thousands hectares of land on daily basis or alternately about 7.8 million hectors on annual basis [3].

Effluents from pharmaceutical industries are called pharmaceutical effluents. Pharmaceutical compounds are being used for human and veterinary medicines several beneficial purposes during the manufacturing, Antibiotics, Analgesics Antiepileptic, Antiseptics, Antihypertensive, Hormones, Contraceptives, and Beta-blockers. They have many organic matter in and heavy metal contents, the excess of these chemicals they have unknown effects on nature of things that we considered to be safe because we would only expect them to be present in trace concentrations [4]. High concentration of these chemical change the bio activity of things and ultimately change the food chain. Inactivating substituent attached to the molecule, depending on the pharmacology of the substance in concern [5]. Pharmaceutical substances used in fish farms will be transfer directly to the receiving waters, because the most convenient method of treating fish with antibiotics and chemotherapeutics is by the use of bed additives Pharmaceuticals compounds in the Environment adopted different routes of incorporated into the fresh water bodies, industrial plants and pharmaceutical effluents, surface of soil (bio solids wastes and water waste reuse) [6]. The physicochemical study of these wastes should showed that these industries follows the standard valued of Federal Environmental Protection Agency (FEPA) [7]. Chemical oxygen demand (COD) is an important pollution index of waste waters is the oxygen valued in biological oxygen demand (BOD), amount of nitrogen and phosphorus in waste water are important for the measurement. Other than these water quality parameters include temperature, $\mathrm{pH}$ and total suspended solids (TSS) [8]. Pharmaceutical effluents are classified into their unusual condition, COD, TDS, TSS, and total hardness. The continuously addition and lower values of complex medical mixtures in water and may cause in toxic and chronic damages [9], [10]. behavioral changes [11], [12], addition in tissues reproductive loss [13], and restriction of cell proliferation [14]. Pharmaceutical industries consist of large number of chemical and biological compounds so these effluents change the quality of water. quality parameters for irrigated water contaminated with these effluents and increase $\mathrm{pH}$, temperature, total dissolved solid (TDS), total solids, total suspended solid, grease, chloride and oil, and increase in water parameters like biochemical oxygen demand (BOD) and chemical oxygen demand (COD), indicated higher pollution level in effluents [16] the concentrations of, BOD, TDS COD, selenium, copper, fluoride arsenic, and iron were recorded 5 to 10 times higher than maximum permissible limit these effluents are rich source of chemical composition of soil, the repeated irrigation of these waste water accumulate appreciable quantities of heavy-metals and micro-nutrients in the soil. The contamination of these parameter in soil also affect the quality of soil and crops. The contents of toxic metals in effluents adversely affect germination, rate of root growth root initiation, stem growth, panicle emergence, and filling of grain. In extreme cases the plant dies because of effluent water application [17] also reported beneficial effects of organic effluents on plants [18] mentioned deleterious effect of industrial effluent in pea germination and initial growth. Therefore, the study was planned to determine the content of different toxic metals accumulation in irrigated soil which translocate them into vegetables. The bioactive characteristics of pharmaceuticals contaminants introduced into irrigated water which produce adverse effects on humans. The adverse effects of veterinary pharmaceutical contamination appeared in other organism [19], [20].

Heavy metals like, $\mathrm{Ni}, \mathrm{Pb}, \mathrm{Cu}$ and $\mathrm{Cd}$ are not essential for growth of plant, they are taken from soil and absorbed by plants in harm level. When they are ingested by human through vegetables irrigated by these effluents create health risk to humans and wildlife. When the soils are continuously irrigated by these sources the concentrations of these heavy metals are increases over the allowable limit. Increasing concentrations of toxic metal in soil are responsible for absorbance of toxic metal by plants in different stages of growth plant species [21].

pharmaceutical industries and other industries like smelting, steel, iron industries and agriculture as well as domestic activities [22], are major sources of toxic metal in effluents and soils. Therefore, the determination the concentrations of these toxic metals in soils become more important. This is not only determine the contents of metal contents but also types of metals.

Lead, Copper, cadmium, zinc, arsenic, aluminum and chromium are present in agricultural soils, from many studies showed that the agricultural soil is effected by toxic metals through again and again use of effluents as a source in irrigation and fertilizers. These toxic metals found in effluents of industries and in many fertilizers and pesticides. $\mathrm{Cd}$, is also found in agricultural soils which is added by effluents and fertilizers, water containing these toxic metals applied for irrigation all toxic elements found in these sources keep accumulating in soil [23].

In these condition, vegetables containing elevated level of toxic metals as compared to those cultivated in unaffected soils because they take these metals. The use of untreated pharmaceutical effluent continuously for production of vegetables may cause absorption of metals in dangerous amounts which is different for different vegetables.

Zinc, lead, chromium, nickel and cadmium are the metals mostly present in green vegetables cultivated in the sites of small industrial estate area Sahiwal. A. A spectrophotometry was used to check and compare the levels of these metals in the vegetables. These pharmaceutical effluents are responsible for elevate level these toxic metals in vegetable of that soils [24]. Heavy metals are not easily biodegradable and through these vegetables metal accumulation takes place in human organs producing unwanted side effect [25], [26]. This condition responsible for varying degree of effects based on these exposures. 


\section{Experimental Work}

The selected area for the sampling of pharmaceutical effluent, soil and vegetables was two kilometers away from small industrial estate Sahiwal. This current research work was carried out in department of Chemistry University of Lahore Sargodha campus and AAS (atomic absorption spectroscopy ) tests was examine with the help of my colleague Mr. Nasir and Radiant pharmaceutical (Pvt). Ltd. Lahore.

The study area of the topic consist three distinct environs effluents, soil, vegetables.

Samples of these environs were collected from different places and time duration.

Nine Effluent samples were collected from a small canal of small industrial estate Sahiwal. Before the collection of Samples, sample bottles were purchased from local market of Sahiwal. Sample bottles were sterilized with sodium Thio Sulphte $\left(\mathrm{NaS}_{2} \mathrm{O}_{3}\right)$ and then washed with double distilled water twice. Three Sample bottles marks with (Effluent Sample surface) E. S. S. I, II and III from 10, 200 and 500 meter respectively and samples were taken from the surface of water. Three Sample bottles marks with (Effluent Sample center) E. S. C. I, II and III from 10, 200 and 500 meter respectively and samples were taken from the center of water. Three Sample bottles marks with (Effluent Sample bottom) E. S. B I, II and III from 10, 200 and 500 meter respectively and samples were taken from the bottom of water point. To avoiding contamination bottles were sealed and the samples ware further preserved for further analysis. $\mathrm{PH}$ and temperature were measured. Polythene bags were purchased from the local market of Sahiwal and labeled S. S. 1.(Soil sample 1) from surface of soil. S. S. 2 (Soil sample 2) from 5 $\mathrm{cm}$ depth of soil and S. S. 3 (Soil Simple 3) from $10 \mathrm{~cm}$ depth of soil. Three sample were collected at three different point. Sample 1 were taken from the surface of the soil. Sample two was taken from $5 \mathrm{~cm}$ depth and sample three were taken from $10 \mathrm{~cm}$ depth and different time. The soil samples were collected from the effluent irrigated fields. The $\mathrm{pH}, \mathrm{EC}$ were checked at the site with $\mathrm{pH}$ Meter and EC meter. After drying in open air it crushed and passed through $2 \mathrm{~mm}$ mesh sieve. For heavy metals extraction, $10 \mathrm{~g}$ of air dried soil is kept in $20 \mathrm{ml}$ of ammonium bicarbonatediethylene tri amine Penta acetic acid AB- DTPA. These mixture were shaken for 15 minutes, then filtered and this filtrate was kept in clean plastic bottles and analyzed for selected metals ( $\mathrm{Cd}, \mathrm{Cr}, \mathrm{Zn}, \mathrm{Cu}, \mathrm{Fe}$, and $\mathrm{Pb}$ ).

The sample of the vegetables were collected randomly from fields along the industrial estate of Sahiwal and first preserved in polythene bags pumpkin sample, green chiliSample and spinach vegetables samples were washed with distilled water and packed in polythene bags for laboratory. The samples were dried and then finely cut into small pieces, Putted in ceramic dishes. Then heated in electric furnace (Carbonated Electric Furnace with ceramic Lining) at $100^{\circ} \mathrm{C}$ for half an hour, after this heating, the second heating was at $300^{\circ} \mathrm{C}$ in a Petri dish the area) after that these samples Placed in covered crucibles at $450{ }^{\circ} \mathrm{C}$ for two hours in an electric furnace. Temperature was increased gradually to avoid the loss of contents by volatilization. After drying and ash making, the organic digestion was done. For this purpose $2 \mathrm{~mL} \mathrm{HNO}_{3}$ to $0.5 \mathrm{~g}$ sample was done and then again heating the sample for half hour then adding $2 \mathrm{~mL}$ hydrogen peroxide to $0.5 \mathrm{~g}$ sample and heating for half an hour. Subsequently multi- acid digestion was done by $10 \mathrm{~mL}$ $\mathrm{HNO}_{3}, 3 \mathrm{~mL} \mathrm{HClO}_{4}$ (Per chloric acid) $+5 \mathrm{~mL} \mathrm{HF}$ (hydrofluoric acid) and placed on a hot plate. Again $5 \mathrm{~mL}$ $\mathrm{HNO}_{3}$ was added in the sample. Leaching of sample was done by adding 1 portion of $\mathrm{HNO}_{3}$ and 1 portion of $(30 \mathrm{~mL}$ each) distilled water in the sample beaker was covered with watch glass then these were placed in hot beaker for 2 hours sample were filtered dried and volume was made $50 \mathrm{~mL}$ with distilled water covered with watch glass [51].

\section{Results and Discussions}

The color of the effluent sample was taken in a test tube containing glass comparator. tube the color of the sample was matching the pure water. Temperature was determine by mercury glass thermometer by direct dipping the thermometer in the effluent sample $\mathrm{pH}$ of the sample was determined on the site using pre-calibrated $\mathrm{pH}$ meter (TS- 1, Suntex Taiwan) electrode was dipped in standard buffer solution of $\mathrm{pH} 7$.

For TSS measurements, a water sample was filtered with weighed What man filter paper 42, then filter paper was washed with deionized water than it was affixed in an own at $100^{\circ} \mathrm{C}$.

After drying and cooling, the quantity of suspended solids calculated in $\mathrm{mg} \mathrm{L}^{-1}$ from the difference of weight.

After investigated soil contents of heavy metals in the study As, Cd levels in all the selected vegetables is higher than WHO and CODEXA limits Arius standard, with maximum concentration were observed in spinach in Pakistan Cd level as $0.24-2.1 \mathrm{mg} / \mathrm{Kg}$ has been investigated in vegetables [65]. And it has also been investigated that $\mathrm{Cd}$ level in aerial part is more than other parts of some vegetables whose stems and leaves are mostly edible should not specifically grown in areas irrigated with effluent.

The observed value of $\mathrm{Cr}$ in all the vegetables ranged from $2.5 \mathrm{mg} / \mathrm{Kg}$ to $4.6 \mathrm{mg} / \mathrm{Kg}$ the highest chromium content $(4.6 \mathrm{mg} / \mathrm{Kg})$ was Spinach as heavy metals accumulate in more roots and leaves. Cr has more absorption tendency in soil but it is not retain long time in the soil and is used up by plants. In the present study, the concentration of chromium is lower in soil but higher in vegetables. Maximum studies including this have shown that $\mathrm{Cr}$ is present in permissible limits 100 $150 \mathrm{mg} / \mathrm{Kg}$ while in global demand it is $60 \mathrm{mg} / \mathrm{Kg}$ According to one study $\mathrm{Cr}$ is $3.74 \mathrm{mg} / \mathrm{Kg}$ in leaves $7.56 \mathrm{mg} / \mathrm{kg}$ in edible parts, spinach irrigated by effluents show high values of chromium $3.93 \mathrm{mg} / \mathrm{Kg}$ as compared to fresh water $0.004 \mathrm{mg}$ $/ \mathrm{Kg}$. Lead is also higher in leafy parts spinach $0.3 \mathrm{mg} / \mathrm{Kg}$ and fruiting vegetables $0.1 \mathrm{mg} / \mathrm{Kg}$ this revealed that $\mathrm{Pb}$ was at high concentrations than permissible limits. other studies in 
Pakistan showed in vegetable ranging lead level 0.03 to 0.4 $\mathrm{mg} / \mathrm{Kg}$

In present study it has showed that all vegetables samples exceeded $\mathrm{Zn}$ permissible limits with maximum concentration in spinach while iron is not harming to plants.

The concentration of $\mathrm{Fe}$ was within the safe limits in all the vegetables.

The trends of heavy metals observed in selected vegetables were as follows:
$\mathrm{Cu}=$ Spinach $>$ Pumpkin $>$ Green Chili

$\mathrm{Pb}=$ Spinach $>$ Pumpkin $>$ Green Chili

$\mathrm{Fe}=$ Spinach $>$ Green Chili $>$ Pumpkin

$\mathrm{Zn}=$ Green Chili $>$ Spinach $>$ Pumpkin

$\mathrm{Cr}=$ Spinach $>$ Pumpkin $>$ Green Chili

$\mathrm{Cd}=$ Spinach $>$ Pumpkin $>$ Green Chili

Results of current study have shown that irrigation with pharmaceutical effluents increase the concentration of toxic metal in soil and vegetables (Table 1 \& Figure 1).

Table 1. Irrigation with pharmaceutical effluents increase the concentration of toxic metal in soil and vegetables.

\begin{tabular}{lllllll}
\hline Samples & $\mathbf{C d}(\mathbf{m g} / \mathbf{K g})$ & $\mathbf{P b}(\mathbf{m g} / \mathbf{K g})$ & $\mathbf{Z n}(\mathbf{m g} / \mathbf{K g})$ & $\mathbf{F e}(\mathbf{m g} / \mathbf{K g})$ & $\mathbf{C r}(\mathbf{m g} / \mathbf{K g})$ & $\mathbf{C u}(\mathbf{m g} / \mathbf{K g})$ \\
\hline Effluents & $0.7 \pm 0.00$ & 4.5 & 4.0 & 155 & 8.5 & 0.08 \\
Soil & 6 & 22 & 328 & 60 & 5.0 \\
Pumpkin & 1.1 & 1.5 & 270 & 7.0 & 35 \\
Spanch & 1.0 & 2.24 & 260 & 1.1 & 9 \\
Green chili & 1.12 & 0.3 & & 9.0 & 4.2 \\
\hline
\end{tabular}

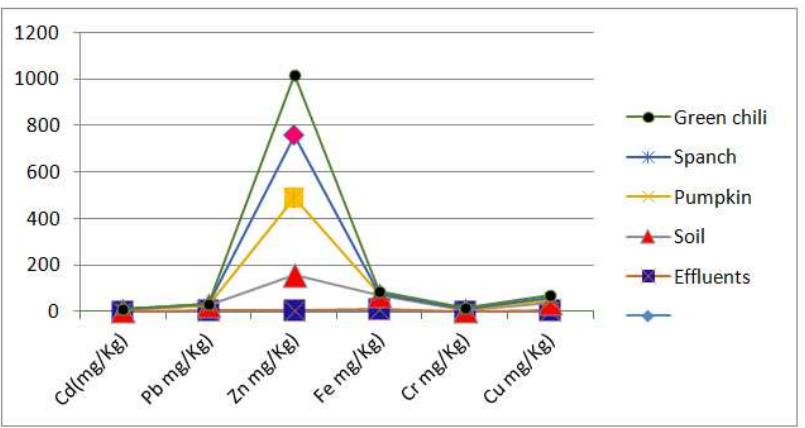

Figure 1. Toxic matels conc $(\mathrm{mg} / \mathrm{kg})$. Vs vegetables.

\section{Conclusions}

It was concluded that toxic metal concentrations were increased in irrigation water of small industrial area Sahiwal by discharging pharmaceutical effluents in the following order $\mathrm{Fe}>\mathrm{Pb}>\mathrm{Zn}>\mathrm{Cu}>\mathrm{Cr}>\mathrm{Cd}$ and when the agricultural soil irrigated with water,

The contents of these toxic metals aggregate in the soil by the order, $\mathrm{Fe}>\mathrm{Cu}>\mathrm{Zn}>\mathrm{Pb}>\mathrm{Cd}>\mathrm{Cr}$. All the metals in the vegetable samples $\mathrm{Zn}$ was higher than permissible level in spinach while Iron was present in higher concentration but this is not dangerous for plants nontoxic to plants. Results of this study have shown that toxic metals in vegetables irrigated with effluents of pharmaceuticals accumulate in the different parts of vegetables

\section{References}

[1] Halling, B.; Lanzky, P.; Nielson, S, N.; Ingerslev, F.; Holten, J.; Lutzhoft, S.; Jorgensen, E,; Occurrence, fate and effects of pharmaceutical substances in the environment. Chemosphere. 2002, 35, 357-393.

[2] Duffus, HJ.; Heavy metals IUPAC Technical Report. Pure Appl. Chem. 2002, 74, 793 - 807 Jain, CK.; Bandypadhyay, A.; Bhadra, A.; Assessment of ground water quality for drinking purpose, District Nainital, Uttarakhand, India. Environment Monitoring Assessment. 2010, 166, 663-676.
[3] Colburn, T.; Clement, C.; Chemically - Induced alterations in sexual and functional development. The wildlife/Human connection, advances in modern environment taxonomy. Princeton Scientific, Princeton. 1992, 21, 129-145.

[4] Rang, H. P.; and Dale, M. M.; Dales pharmacology, Churchill livingstone. Second addition, 1991, 15, 955-980.

[5] Daughton, C. G.; Ternes, T. A,; Pharmaceutical and personal care products in the environment.. Environmental Health Perspectives, 1999, 107, 907-938.

[6] Federal Environment Protection Agency FEPA FG Press Lagos Nigeria. 238.

[7] Ezenobi, N. O.; Okpokwasili, G. C.; Responding to oil spills in the US. Nigerian Journal of Microbiology, 2004, 18, 1-2.

[8] Watts, C.; Crane, M.; Boucard, T.; Chronic environmental risk exposure to human pharmaceuticals. Science of the total Environment, 2006, 367, 23-41.

[9] Quinn, B.; Gagne, F.; Blaise, Evaluation of acute, chronic and teratogenic effects of mixture of eleven pharmaceutical on cnidarian. Science of the total environment. 2008, 389, 10721079 .

[10] Klaine, S.; Gaworecki, G.; Behavioral and biochemical response of hybrid striped bass during and after fluoxetine exposure. Aquatic toxicology, 2008, 88, 207-213.

[11] Chambliss, C.; Stanley, J.; Ramirez, A.; Brook, W.; enatinspecific sublethal effects of antidepressant fluoxetine to a model aquatic vertebrate and invertebrate. Chemosphere, 2007, 69, 9-16.

[12] Turner, P.; Brooks, B.; Stanley, J.; Weston, J.; Glidewell, E,; Foran, C.; Slattery, M.; Point, W.; Hugget, D.; water born and sediment toxicity of fluoxetine to organism. chemosphere, 2003, 52, 135-142.

[13] Nentwing, G.; effects of pharmaceutical on aquatic invertibrates. environmenal contamination and toxicology, 2007, 52, 163-170.

[14] Castiglioni, S.; Pomti, F.; Zuccato, E.; Fanelli, R.; Vigetti, D.; Calamari, D.; effects of mixture of complex therapeutic drugs at environmental level on human emberyonic cell. Environmental sceience and technology, 2006, 40, 2442-2447. 
[15] Brain, R.; Sanderson, H.; Johnson, D.; Reitsma T.; Wilson, C.; Solomon, K.; regulatory and pharmacology, 2004, 39 (2) 39, 158-164.

[16] Kumar, H. D.; Modern Concept of Ecology, New Delhi: Vikas Publishing House Pvt. Ltd. 1990, 29, 218-75.

[17] Agrawal, S. K.; Swanlalat, R.; and Deubey, P. S.; Biodiversity and Environment. New Delhi.. APH Publishing Corporation, $1996,179-184$.

[18] Ternes, T.; technologies assessment for the removal of pharmaceutical and personal care products in sewage and drinking water to improve the indirect potable water reuse. 2004, EU EVKI-CT-2000-2047.

[19] Koenig, B.; Metcalfe, C.; Hirsh, R.; Druges in sewages reatment plants effluents in Canada, 2000, proceedings, American chemical society national meeting- spring, san Francisco, CA, 100-104.

[20] Franks, F.; and Ives, D. G.; The structural properties of alcohol-water mixtures. Q. Rev. Chem. Soc. 1966, 20, 1-44.

[21] Panday, J. D.; Shukla, A.; Rai, R. D.; Mishra, K. J.; Ultrasonic, volumetric and viscometric studies of tetracycline and its allied compound. J. Chem. Eng. Data. 1989, 34, 29-31.

[22] Snow, E.; Tanaka, A.; Alam, M.; Arsenic and heavy metal concentration of vegetables grown in Samta village Bangladesh. The science of total environment, 2003, 111, 811815 .

[23] Mohon, D.; Singh, K.; Dalwani, R.; assessment of unwanted waste water, chemosphere, 2004, 55, 227-235.

[24] Jarup, L.; Hazrds of heavy metal contamination, British med. Bull, 2003, 68, 167-182.

[25] Parikh, D.; Sathawara, N,; Agarwal, Y.; Essential heavy metal in environment samples. Environ contam. toxicol, 2004, 73, 264-269.

[26] Pyatt, F.; Wilson, B.; Heavy metal dipersion persistence and bioaccumulation around an ancient an ancient copper mine situated Anglesey UK. Ecotoxicol environ Saf. 2007, 66, 224231.

[27] WHO. World health organization Sixty-First Report of the joint FAO/WHO Series, 2004, 922; Evaluation of Certain Food Additives and Contaminants.

[28] Pendias, A.; Pendias, heavy metals in plants and soils. FL, United state CRC press 2000, 3, 3-11.

[29] Staney, S.; Malcolm, S.; The sedimen environment in sediment microbiology. Eds. Nedell D. B. and brown C. M, publishers 1982. Academic press ins. London.

[30] Yagi, M.; Nakashima, S.; Aoyama, I,; analysis of chemical fractions of heavy metals. Nogacu Kenkye, 1985 ,(4) 150-157.

[31] Khan, M, H.; Yasmin, N.; Metallic pollution in water and food items of industrial city by atomic absorption spectroscopy, Pak. J. Bio. Sci., 2003, 6 (14) 1276-1281.

[32] Soon, Y. K.; Bates, T. E.; Moyer, J. R.; "Land Application of Chemically Treated Sewage Sludge II. Effects on Plant and Soil Phosphorus. Potassium, Calcium and Magnesium and Soil pH.” J. Environ. Qual. 1978, 7, 269-74.

[33] Page, A. L.; Miller, R. H.; Keeney, D. R.; Methods of Soil
Analysis. Part 2-Chemical and Microbiological Properties. 2nd edition, Agronomy 9. ASA, Madison, WI. (Eds.), 1986, 1159-1172.

[34] Al-Subu, M. M.; Salim, R.; Douleh, A.; Atallah, A.; Combined effects of Cadmium, Lead and Copper on the growth and on metal uptake of broad beans, carrots, radishes and marrow vegetables. Rev. Int. Contam. Ambient. 1993, 9 (1) $1-9$.

[35] Islam, Md.; Lahermo, R.; Salminen, W. P.; Rojstaczer, R., S.; Peuraniemi, V. J.; Lake and reservoir water quality affected by metals leaching from tropical soils, Bangladesh. Environ. Geol., 2000, 39, 1083-1089.

[36] Jamroz, N.; and Burki, A. M.; Drinking water quality in Hatter Industrial Estate (HIE), district Haripur, Pakistan. Pak. J. Anal. Chem., 2002, 3, 1-63.

[37] Sarker, B. C.; Zaman, M. W.; Biswas, J. K.; Rahmatullah, N. M.; Uddin, M. N.; "Ionic Toxicity and Suitability Assessment of Waste Water and Pond Water for Irrigated Agriculture in Narayanganj District of Bangladesh." Bangladesh J. Agril. Res. 2003, 28 (3), 291-300.

[38] Khan, M, H.; Yasmin, N.; Study of metallic pollutants in water and food items of an industrial city by Atomic Absorption Spectrophotometry. Pak. J. Bio. Sci., 2003, 6 (14), 1276-1281.

[39] Kosjek, T.; Heath, E.; Krbavcic, A.; Determination of nonsteroidal anti-inflammatory drug (NSAIDs) residues in water samples. Environ Int 2005 31, 679-685.

[40] Ahmed, J. U.; and Goni, M. A.; "Heavy Metal Contamination in Water, Soil, and Vegetables of the Industrial Areas in Dhaka, Bangladesh.” Environ Monit 2010, 166, 347-357.

[41] Singh, A.; Sharma, R. K.; Agrawal, M.; Marshall, F.; M. Risk assessment of heavy metal toxicity through contaminated vegetables from wastewater irrigated area of Varanasi, India. Int. Soc. Tropical Ecology, 2010, 52, 375-387.

[42] Khan, K.; Lu, Y.; Khan, H.; Zakir, S.; Ihsanullah, Khan, S.; Khan, A. A.; Wei, L.; Wang, T.; Health risks associated with heavy metals in the drinking water of Swat, northern Pakistan. Journal of Environmental sciences, 2013, 25 (10) 1-10.

[43] Muhammad, S.; Shah, M. T.; Khan, S.; Heavy metal concentrations in soil and wild plants growing around $\mathrm{Pb}-\mathrm{Zn}$ sulfide terrain in the Kohistan region, northern Pakistan. Micro chemical Journal, 2011, 99 (1): 67-75.

[44] Mandour, R. A., Human health impacts of drinking water (surface and ground) pollution Dakahlyia Governorate, Egypt. Applied Water Sciences, 2012, 2 (3): 157-163.

[45] Amin, N.; Hussain, A.; Alamzeb, S.; Begum, S.; Accumulation of heavy metals in edible parts of vegetables irrigated with waste water and their daily intake to adults and children, District Mardan, Pakistan. Food Chemistry. 2013, 136,(3-4): 1515-1523.

[46] Feleafel, M. N., Mirdad, Z. M., 2013. Hazard and effects of pollution by lead on vegetable crops. Journal of Agricultural and Environmental Ethics, 26 (3): 547567.

[47] Iqbal, J.; Shah, M. H.; Akhter, A.; Characterization, source apportionment and health risk assessment of trace metals in freshwater Rawal Lake, Pakistan. Journal of Geochemical Exploration, 2013, 125, 94-101. 
[48] Udebuanil, A. C.; Ofoma1. A. O.; Otitoju. O.; Abara P. P. N.; Ezejiofor T. N.; Cytotoxic and Genotoxic Impacts of Pharmaceutical Effluent from KP Pharmaceutical Industry, ACSJ. 27604, 2016, 16 (2): 1-10.

[49] Shruthi, L.; Shyni. K.; Abhilash, B.; Photocatalytic Degradation And Removal of Heavy Metals in Pharmaceutical Waste by Selenium Doped ZnO Nano Composite Semiconductor Journal for Research |2016, 02, 2395-7549.

[50] Hamid, A.; Riaz, H.; Akhtar, S.; Heavy Metal Contamination in Vegetables, and soil assesment American-Eurasian J. Agric. \& Environ. Sci., 2016, 16 (4): 786-794.

[51] Kachout, S.; Sai, Leclere.; Mansoura, A.; Rejeb, M. N.; and Ouerghi, Z.; Effects of Heavy metals on growth and bioaccumulation of the annual Halophytes Atriplex Hortensis and A. Rosea. J. Appl. Sci. Res., 2009, 5 (7): 746-756.

[52] WHO:

http://www.who.int/water_sanitation_health/emerging/info_sh eet_pharmaceuticals/ en/index.html accessed on 5 June, 2013,

[53] Ismail, F.; Anjum, M. J.; Mamon, A. N.; Kazi, T. G.; Trace metal contents of vegetables and of Hyderabad Retail Market. PJN. 2011, 10 (4) 365-372.

[54] Khan, S.; Aijun, S.; Zhang, Q. Hu.; Zhu, Y. G.;. Accumulation of polycyclic aromatic hydrocarbons and heavy metals in lettuce grown in the soils contaminated with long-term wastewater irrigation. J. Hazard. Mater. 2008, 152, 506-515.

[55] Mahmood, A.; Malik, R. N.; Human health risk assessment of heavy metals via consumption of contaminated vegetables collected from different irrigation sources in Lahore, Pakistan. Arab J. Chem., 2014. 7, 91-99

[56] -Sarker, B. C.; Baten, M. A.; Haque, M.; Das, A. K.; Hossain, A.; and Hasan, M. Z Heavy Metals Concentration in Textile and Garments Industries' Wastewater of Bhaluka Industrial Area, Mymensingh, Bangladesh. Curr World Environ., 2015, 10 (1): 61-66.

[57] Bashir, F.; Kashmiri, M. A.; Tahira. S.; and Tariq, M.; Heavy metals uptake by vegetables growing in sewage irrigated soil: relationship with heavy metal fractionation in soil. Chem Specia \& Bioavail., 2009, 21 (4): 199-209.

[58] NEQS (National Environmental Quality Standards), Ministry of Environment, Government of Pakistan, Pakistan Environmental Legislation, 2000.

[59] Sarker, B. C.; Baten, M.; Haque, E.; Das, A.; Hasan, M. Z.; Heavy Metals Concentration in Textile and Garments Industries' Wastewater of Bhaluka Industrial Area, Mymensingh, Bangladesh. Curr World Environ, 2015, 10 (1) 61-66.

[60] World Health Organization (WHO), Guidelines for the safe use of wastewater, excreta and greywater: Wastewater use in agriculture 2006, (Vol II), World Health Organization. Geneva.

[61] Perveen, S.; Samad, A.; S. Muhammad, M. T.; Shah Heavy metal concentrations in soil and wild plants growing around $\mathrm{Pb}-\mathrm{Zn}$ sulfide terrain in the Kohistan region, northern Pakistan. Microchem J. 2011, 99 (1), 67-75.

[62] Gogoasa and I. Gergen, Heavy metals health risk assessment for population via consumption of vegetables grown in old mining area; a case study: Banat County, Romania. Chem Cen J. 2011. 5, 1-64.

[63] WHO/FAO, 2007. Joint FAO/WHO Food Standard Programmed Codex Aliment Arius Commission 13th Session. Report of the Thirty Eight Session of the Codex Committee on Food Hygiene. Houston, TX, USA.

[64] Perveen, S. A.; Samad, S.; Muhammad, M. T.; Khan, S.; Heavy metal concentrations in soil and wild plants growing around $\mathrm{Pb}-\mathrm{Zn}$ sulfide terrain in the Kohistan region, northern Pakistan. Microchem J. 2011, 99, 67-75.

[65] Yargholi, B.; Azimi, A.; Investigation of Cadmium absorption and accumulation in different parts of some vegetables. $\mathrm{Am}$ Euras. J. Agric \& Environ. Sci. 2008, 3 (3): 357-364.

[66] Farooq, M.; Anwar, A.; Rashid, U.; Metal contents in vegetables grown on an Industrial area. Pak. J. Bot., 2008 , 40 (5) 2099-2106. 